\title{
3D Finite Element Model for Shear-dominant Failure of Reinforced Concrete Beams
}

\author{
Ridwan $^{1, *}$ () , Ilham Akbar ${ }^{2}$, and Rofriantona ${ }^{3}$ \\ ${ }^{1}$ Dept. of Civil Engineering, Universitas Riau, Pekanbaru, Riau, Indonesia, 28293 \\ ${ }^{2}$ Dinas Pekerjaan Umum dan Penataan Ruang Kota Pekanbaru, Riau, Indonesia \\ ${ }^{3}$ Dinas Pekerjaan Umum, Penataan Ruang, Perumahan, Kawasan Permukiman dan Pertanahan Provinsi Riau, Pekanbaru, Riau, \\ Indonesia
}

\begin{abstract}
This study explores the 3D FE modelling approach in determining the behaviour of shear-dominant responses of $\mathrm{RC}$ beams. Five RC beams (A1, A2, B1, C2 and C3) with different cross-sections, amount of tension reinforcement area, amount of shear reinforcement and the length of the span was analysed and the results were compared with the results of the experiment and 2D analysis available in published literature. RC beams analysed in this FE study were constructed as a discrete model using ABAQUS software. The concrete and the plate for loading as well as for supports were modelled using the C3D8R element while longitudinal steel bars and stirrups were modelled with the T3D2 element. The interaction between the steel bar and the concrete in the FE model was assumed perfectly bond. The material behaviour of concrete was modelled with the damage plasticity model where the yield or failure of the material was governed by the tensile cracking and the compressive crushing of the concrete by introducing the hardening variables. The results showed that crack propagation in the FE analysis matched the cracks observed in the test. The crack pattern on Beam A1, A2, B1 and C2 indicated that the specimens experienced flexure and shear failure while Beam C3 experienced less brittle behaviour. Estimates of strength and the load-deformation response of 3D analysis were certainly achieved with reasonable accuracy compared to that of $2 \mathrm{D}$ analysis. The difference of experiment-to-2D strength $\left(P_{u, \text { exp }}-P_{u, 2 D} / P_{u, \text { exp }}\right)$ had a mean of 4.53 whereas the difference of experiment-to3D strength $\left(P_{u, \text { exp }}-P_{u, 3 D} / P_{u, \text { exp }}\right)$ had a mean of 1.83. Furthermore, the displacements at ultimate load gained in the $3 \mathrm{D}$ analysis were comparable to those of experiments. The difference of experiment-to-2D $\left(\delta_{u, \exp }-\delta_{u, 2 D} / \delta_{u, \text { exp }}\right)$ and experiment-to-3D $\left(\delta_{u, \exp }-\delta_{u, 3 D} / \delta_{u, \exp }\right)$ midspan displacement had a mean of 19.91 and 10.89 , respectively.
\end{abstract}

Key words: 3D model, FE analysis, RC Beam, Crack Pattern, Load-displacement

\section{INTRODUCTION}

Building structures have grown considerably and more sophisticated as economies have grown in size and complexity. The assessment of the safety and serviceability of these complex buildings demands the development of precise and dependable methodologies and models for their investigation. To maintain the safety of structures, both analytical and experimental studies on structural behaviour under overload situations and or cyclic loads are conducted concurrently, however, experimental investigations are costly, laborious, as well as provide limited information. It is critical to properly explain the behaviour of reinforced concrete (RC) structures under over-load circumstances and predict their ultimate strength, especially for RC structures that are brittle when compared to steel structures $[1,2]$.

Analytical studies have been more common in recent years as a result of computer advancements, developments in analytical procedures, and clear definitions of material characteristics. Since structural analysis requires a significant amount of computational effort for iterations, and numerical instability occurs as working stress increases due to variations in structural appearance and material properties, researchers have to develop simplistic analytical methods that lessen computational time while estimating the ultimate loading capacity of structures.

Finite element (FE) analysis of RC elements of structures is primarily conducted by using $1 \mathrm{D}$ and $2 \mathrm{D}$ models. Discretization of such structures in $1 \mathrm{D}$ or $2 \mathrm{D}$ models requires small effort but shows high numerical stability during the computation especially for the case of large structures with huge degrees of freedom [3]. Nonlinear $\mathrm{FE}$ analysis of the RC beam was developed based on the moment-curvature relationship of the RC section. Softening part of concrete material in tension and the plastic hinge length was included in FE modelling so that imprecision in calculating the flexural capacity was avoided [2]. Moreover, these efforts showed a good agreement with the behaviour of $\mathrm{RC}$ beams that dominantly fail in flexure $[2,4,5]$. However, the bond-slip effect adhered to over reinforced beams was not applicable since modelling the over-RC structure with the beam element imposes some constraints [2].

$\begin{array}{ll}\text { Received } & \text { : October 25, 2021 } \\ \text { Revised } & \text { : January 20, 2022 } \\ \text { Accepted } & \text { : January 23, 2022 }\end{array}$


Table 1 Relevant details of beams analysed in FE study [11]

\begin{tabular}{|c|c|c|c|c|c|c|}
\hline Beam IDs & $\begin{array}{l}\text { Width } \\
(\mathrm{mm})\end{array}$ & Height (mm) & $\begin{array}{l}\text { Span } \\
(\mathrm{mm})\end{array}$ & $\begin{array}{l}\text { Bottom rein- } \\
\text { forcement }\end{array}$ & Top reinforcement & Stirrup \\
\hline Beam A1 & 305 & 552 & 3660 & $\begin{array}{l}2 \mathrm{M} 30 \\
2 \mathrm{M} 25\end{array}$ & $3 \mathrm{M} 10$ & D5-210 \\
\hline Beam A2 & 305 & 552 & 4570 & $\begin{array}{c}2 \mathrm{M} 30 \\
\text { M30 } \\
2 \mathrm{M} 25\end{array}$ & $3 \mathrm{M} 10$ & D5-210 \\
\hline Beam B1 & 229 & 552 & 3660 & $\begin{array}{l}2 \mathrm{M} 30 \\
2 \mathrm{M} 25\end{array}$ & $3 \mathrm{M} 10$ & D5-190 \\
\hline Beam C2 & 152 & 552 & 4570 & $\begin{array}{l}2 \mathrm{M} 30 \\
2 \mathrm{M} 25\end{array}$ & $3 \mathrm{M} 10$ & D5-210 \\
\hline Beam C3 & 152 & 552 & 6400 & $\begin{array}{l}2 \mathrm{M} 30 \\
2 \mathrm{M} 25\end{array}$ & $3 \mathrm{M} 10$ & D4-168 \\
\hline
\end{tabular}

Current FE modelling approaches accurately predicted flexural response of RC elements of structure, however, research to study the response under shear loading is less common [6]. Dual-section analysis along with the Modified Compression Field Theory (MCFT) was developed to determine the shear response of $\mathrm{RC}$ beam under shear loading [7]. In MCFT, crack in concrete developed in its principal direction, namely principal compressive and tensile strain. The MCFT has been extended to be included in the simulation of RC panels and shear walls subjected to cyclic loading $[8,9]$. However, this model was not capable of predicting the local effects that occurred in the disturb zones, i.e support and loading zone. These numerical instabilities were overcome by introducing the longitudinal stiffness method [10]. Concrete in compression followed the formulation of Popovic's curve while concrete in tension was linear up to cracking followed by the tension stiffening behaviour. This approach was capable of predicting the RC sections subjected to the combination of axial, flexure and shear loading. However, due to the restriction of the MCFT fibre constitutive law used in the solution procedure, the response for $\mathrm{RC}$ components without shear reinforcement was not satisfied.

\section{METHODOLOGY}

The modelling of RC beams with the threedimensional finite element (FE) analysis program ABAQUS is presented in this study. For the representation of concrete, the concrete damage plasticity (CDP) model was being used. The modelling procedure was provided after a concise theoretical background on the CDP model. The model was verified by modelling the behaviour of beams previously evaluated at the University of Toronto's structural lab [11]. The numerical findings, e.g crack propagation and load-displacement response were compared to the results of the experimental tests as well as the $2 \mathrm{D}$ calculation using disturb stress field model (DSTM) approach developed by the author [11]. Furthermore, the sensitivity of the FE model to various model parameters is addressed, and the model's critical parameters are determined.

\subsection{Reinforcement Details and Set Up for Toronto Beams}

Figure 1 depicts details reinforcement of RC beam analysed in this study and Table 1 provides relevant details of the tested beams. Three series of beam with different cross -sections, amount of tension reinforcement area, amount of shear reinforcement and the length of span was constructed and tested to study the behaviour of RC beams under shear loading [11]. M30 and M25 steel bars were used for tension reinforcement bars while M10 steel bar was used for compression reinforcement bar. All beams used D5 deformed bars D4 as shear reinforcement except Beam C3. In this case, Beam C3 was reinforced with D4 deformed bars for stirrup.

Figure 2 shows the experimental setup of beams analysed in this study. The beams were placed on hinge and roller supports to mimic a simply-supported structure mechanism and the load was applied at the middle of the beam span using a $2700 \mathrm{kN}$ servo-controlled universal testing machine. During the test, the beam was instrumented with the load cell the LVDT to measure the load and displacement at the midspan. At the beginning of the test, the load were given in the form of load-control with the increment of $40 \mathrm{kN}$ and then, the load near the failure was switched to the displacement control [11].

\subsection{Material Properties}

Table 2 shows the material properties of reinforcement steel bars for the respective beams analysed in this study. There were two different properties for M25 bar size, denoted with superscripts $a$ and $b$ at the end of the bar size code. M25 a was used as longitudinal reinforcement for specimens Beam A2 and C2 whereas $M 25^{b}$ was used as longitudinal reinforcement for specimens Beam A1, B1 and C3. Two types of deformed bars were used for shear reinforcement. Deformed bar D4 was used as stirrup for Beam D4 whereas deformed bar D5 was used as stirrup for Beam A1, A2, B1 and C2 [11]. 

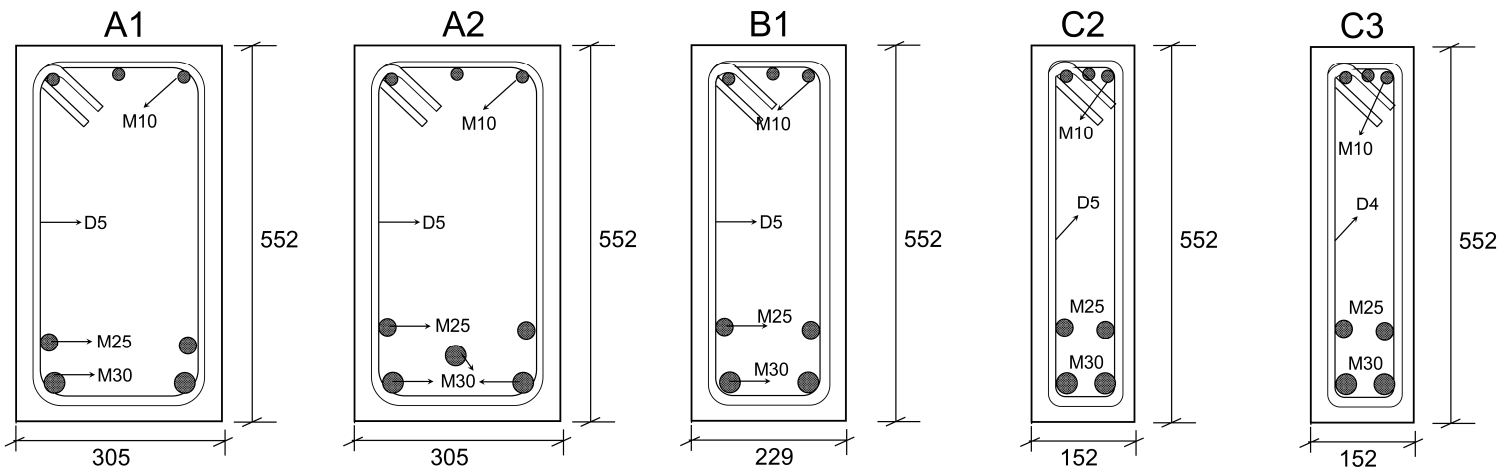

Fig. 1. Details of reinforcement of Toronto beams [11], units in mm : (a) Beam A1, (b) Beam A2, (c) Beam B1, (d) Beam C2, and (e) Beam C3

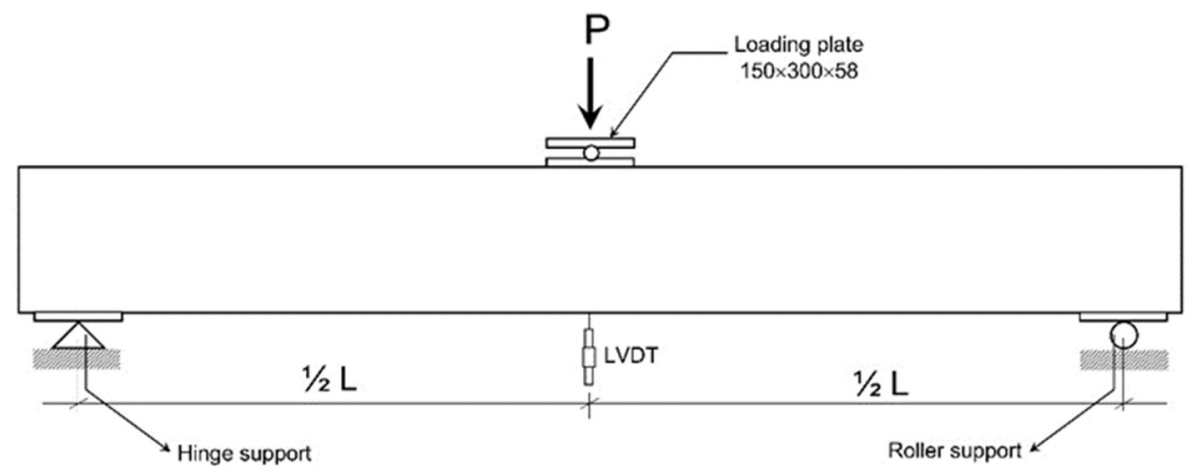

Fig. 2. Experimental setup for beam analysed in FE study [11]

Table 2 Properties of reinforcement steel bars [11]

\begin{tabular}{ccccc}
\hline $\begin{array}{c}\text { Bar } \\
\text { size }\end{array}$ & $\begin{array}{c}\text { Diameter } \\
(\mathrm{mm})\end{array}$ & $\begin{array}{c}\text { Yield } \\
\text { strength } \\
(\mathrm{MPa})\end{array}$ & $\begin{array}{c}\text { Ultimate } \\
\text { strength } \\
(\mathrm{MPa})\end{array}$ & $\begin{array}{c}\text { Modulus of } \\
\text { elasticity } \\
(\mathrm{MPa})\end{array}$ \\
\hline $\mathrm{M} 10$ & 11.3 & 315 & 460 & 200000 \\
$\mathrm{M}^{\mathrm{a}} 5^{\mathrm{a}}$ & 25.2 & 440 & 615 & 210000 \\
$\mathrm{M}^{\mathrm{b}}$ & 25.2 & 445 & 680 & 220000 \\
$\mathrm{M} 30$ & 29.9 & 436 & 700 & 200000 \\
$\mathrm{D} 4$ & 3.7 & 600 & 651 & 200000 \\
$\mathrm{D} 5$ & 6.4 & 600 & 649 & 200000 \\
\hline
\end{tabular}

Table 3 Properties of concrete at the date of test [11]

\begin{tabular}{cccc}
\hline Beam IDs & $\begin{array}{c}\text { Concrete } \\
\text { strength } \\
(\mathrm{MPa})\end{array}$ & $\begin{array}{c}\text { Tensile } \\
\text { strength } \\
(\mathrm{MPa})\end{array}$ & $\begin{array}{c}\text { Modulus of } \\
\text { elasticity } \\
(\mathrm{MPa})\end{array}$ \\
\hline Beam A1 & 22.6 & 2.37 & 36500 \\
Beam A2 & 25.9 & 3.37 & 32900 \\
Beam B1 & 22.6 & 2.37 & 36500 \\
Beam C2 & 25.9 & 3.37 & 32900 \\
Beam C3 & 43.5 & 3.13 & 34300 \\
\hline
\end{tabular}

Table 3 shows the material properties of concrete at the date of beam's tests for the respective specimens analysed in this FE study. The concrete strength varied since the tests were conducted on beams at different concrete ages. Beam A1 and B1 were tested at the concrete age of 38 days, whereas Beam A2 and C2 were tested at the age of 51 days, and Beam C3 was tested at the age of 127 days. The tensile strength of concrete shown in Table 3 was gained through a cylinder split test [11].

\subsection{Finite Element Modelling for RC Beams}

\subsubsection{Geometric Model for RC Beams}

RC beams analysed in this FE study (see Figure 3) were constructed as a discrete model using ABAQUS software [12]. The concrete and the plate for loading as well as for supports in Figure 3.a are modelled using 8-node solid element combined with reduced integration, C3D8R, while both longitudinal steel bars and stirrups in Figure 3.b is modelled with 2-node truss element, T3D2. Several attempts had been successfully done in the past in modelling RC structure elements in ABAQUS using this type of element $[13,14,15,16,17]$. On the other hand, there was no slip between the concrete and the steel bars reported during the test [11] so the interaction between the steel bar and the concrete in the FE model is assumed perfectly bond.

\subsubsection{Model for Material Behaviour}

In this FE study, the material behaviour of concrete is modelled with the concrete damage plasticity (CDP) model. The CDP model in ABAQUS is originally developed based on the work of Lubliner et al. [18] and Lee and Fenves [19]. In the CDP model, the yield or failure of the material is governed by the tensile cracking and the compressive crushing of the concrete by introducing the hardening variables, $\tilde{\varepsilon}_{t}^{p l}$ and $\tilde{\varepsilon}_{c}^{p l}$. The typical failure of concrete in the deviatoric plane and in the plane-stress condition is depicted in Figure 4. 
loading plate

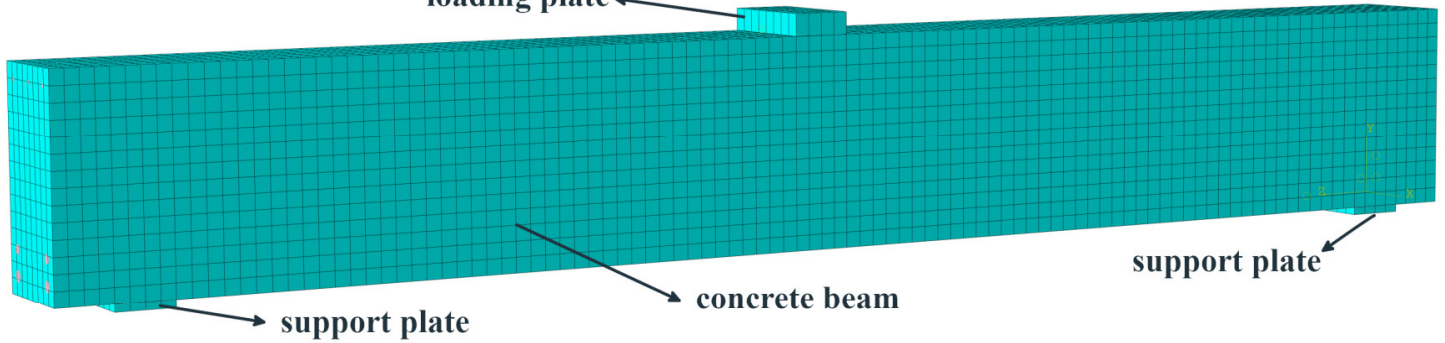

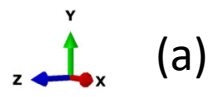

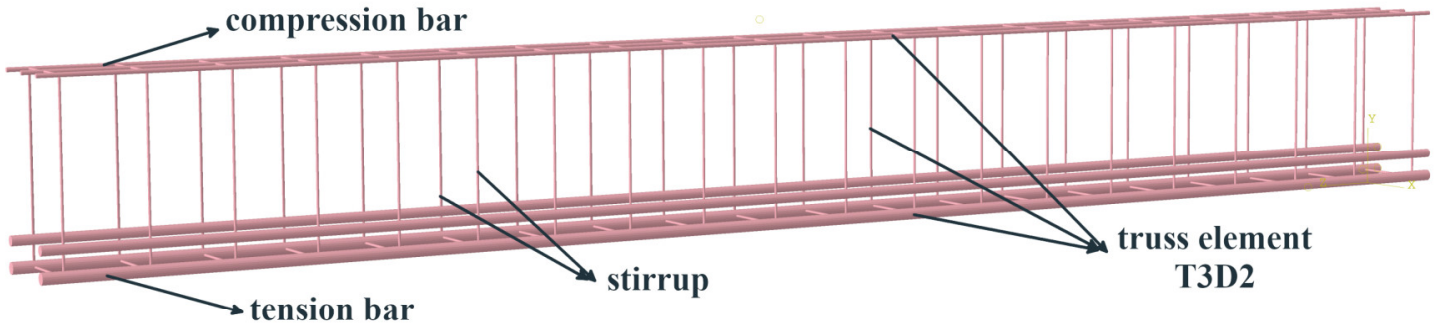

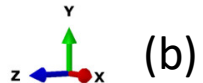

Fig. 3. Discrete model for analysed beam in FE (a) Concrete, support plate and loading plate, (b) reinforcement steel bars
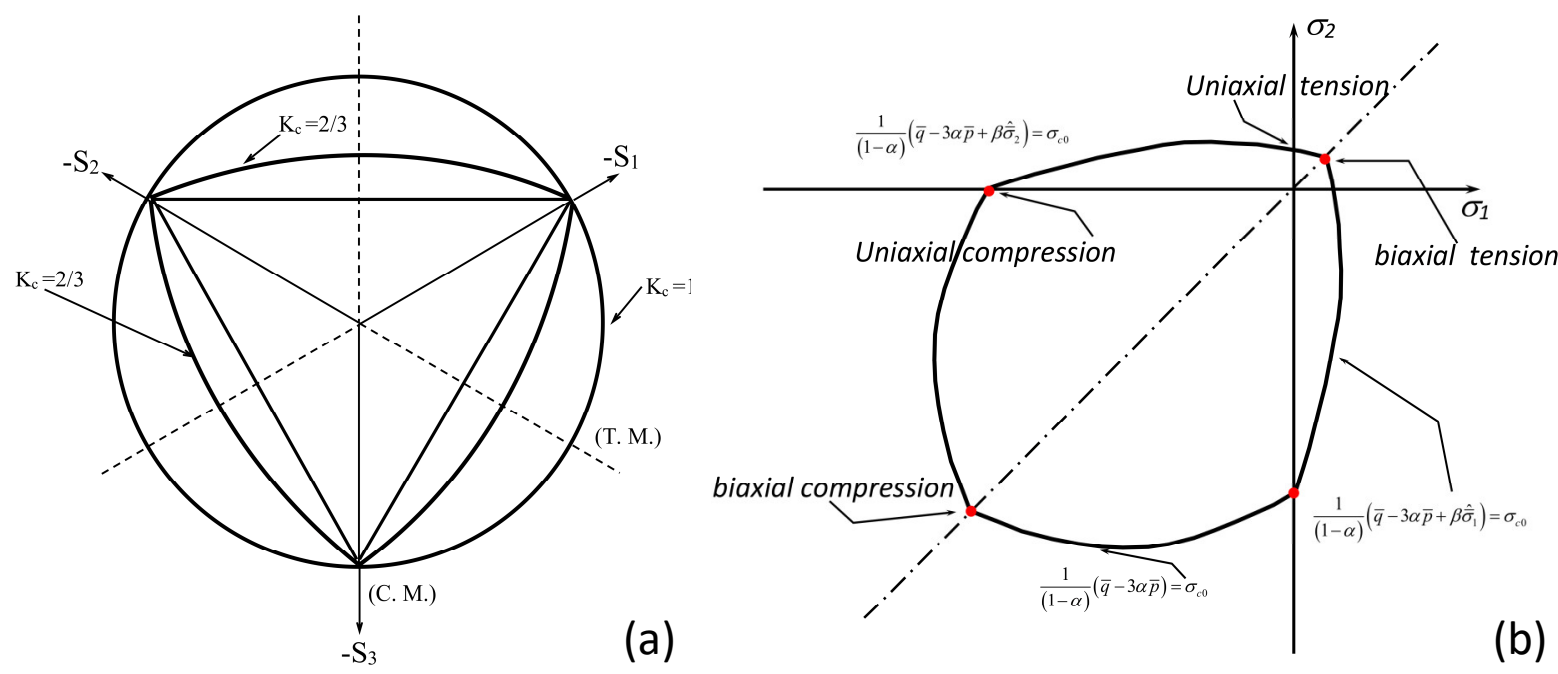

Fig. 4. Failure of concrete in CDP model: (a) deviatoric plane; (b) plane-stress condition [12]

$K_{c}$ in Figure $4 \mathrm{a}$ denotes the failure surface in the deviatoric plane. The default value of $K_{c}$ in ABAQUS is 2/3, but in general, the $K_{c}$ lies in the range between 0.5 and 1.0.

Uniaxial compression of concrete is defined with the equation suggested by CEB-FIP Model Code 1990 [20].

$$
\sigma_{c\left(\varepsilon_{c}\right)}=\frac{E_{c i} \frac{\varepsilon_{c}}{f_{c}^{\prime}}-\left(\frac{\varepsilon_{c}}{\varepsilon_{c i}}\right)^{2}}{1+\left(E_{c i} \frac{\varepsilon_{c}}{f_{c}^{\prime}}-2\right) \frac{\varepsilon_{c}}{\varepsilon_{c i}}} f_{c}^{\prime}
$$

with $\sigma_{c}$ is the concrete stress under compression, $E_{c i}$ is the secant modulus of the concrete stress-strain curve, $\varepsilon_{c}$ is the concrete strain, $f_{c}^{\prime}$ is the concrete strength in $\mathrm{MPa}$, and $\varepsilon_{c i}$ is the strain at the peak of concrete strength. $E_{c i}$ can be calculated using the following equation.

$$
E_{c i}=\frac{1}{2 E_{c}}\left(\frac{f_{c}^{\prime}}{\varepsilon_{c}}\right)^{2}-\frac{f_{c}^{\prime}}{\varepsilon_{c}}+\frac{3}{2} E_{c}
$$

with $E_{c}$ is the initial modulus of elasticity of the concrete. In this study, $E_{c}$ is defined with the following equation

$$
E_{c}=3320 \sqrt{f_{c}^{\prime}}+6900 \mathrm{MPa}
$$


On the other hand, the response of concrete in uniaxial tension is defined with the equation suggested by Bažant and Planas [21].

$$
\sigma_{t(\varepsilon)}=f_{c t} \times e^{\left(\varepsilon_{t}-s\right) / \gamma_{t}}
$$

with $\sigma_{t}$ is the concrete stress under tension, $\mathcal{E}_{t}$ is the concrete strain at the tensile strength of the concrete, $f_{c t}$ is the concrete strength in tension, and $\gamma_{t}$ is the value that defines the fracture energy. $\gamma_{t}$ is calculated with equation

$$
\gamma_{t}=\frac{G_{f}}{l_{e q} f_{c t}}-\frac{1}{2} \frac{f_{c t}}{E_{c}}
$$

The uniaxial stress-strain behaviour of reinforcement bars under tension is modelled with a bilinear curve. In the bilinear curve, the stress-strain of the steel curve is defined with elastic and the strain hardening region is defined with the straight line starting from the elastic limit to the rupture of steel.

The properties of the material for concrete and reinforcement bars used in the FE model is listed in Table 2 and Table 3. These properties include the yield strength, ultimate strength and modulus of elasticity of steel as well as the compressive strength, tensile strength and modulus of elasticity of the concrete.

\section{RESULTS}

\section{1 Crack Propagation}

Figures 5(a), (c), (e), (g) and (i) indicate the crack propagation in the experiment [11]. In general, flexural cracks initiated followed by the appearance of the diagonal cracks in the middle third of the beam depth in the shear span. With the increased loading, diagonal cracks extended in the upward and downward directions. Under the case of the beam with intermediate loading span and web reinforcement, the specimens failed in shear. The failure occurred due to the splitting of the concrete in the compression zone.

Beams A1, A2, B1 and C2 had shear span-to-depth ratios of 4 and 5 . As reported in the test [11], Beams A1, A2, $\mathrm{B} 1$ and $\mathrm{C} 2$ experienced shear compression failure. The failure occurred at loads significantly larger than the load at which the initial diagonal tension crack developed. Increasing load resulted in further diagonal cracking without obvious signs of distress. Failures formed in the middle of the span without widespread propagation of flexural cracks, suggesting that the failure cause was shear compression. Final failure directly led to splitting in the compression zone but without splitting along the tension reinforcement, which is typical of beams lacking web reinforcement.

On the other hand, Beam C3 experienced a flexural-compression failure which was typical for the beam with a high span-to-depth ratio. The beam collapsed due to the compression zone crushing around mid-span at the region of the highest moment. However, the diagonal tension cracking never progressed to become significant critical cracks, whilst flexural cracks continued to grow upward until a severe compression failure occurred, as is common in over-reinforced concrete beams.
In all cases, crack propagation in the $\mathrm{FE}$ analysis matched the cracks observed in the test. Since the geometric and loading scheme of the specimens were symmetric, only half of the crack pattern of the beam was indicated with the addition of the number of crack occurrences. Figures 5(b), (d), (f), (h) and (j) show the cracks propagation gained in the FE analysis. Cracks propagation gained in the FE analysis were depicted based on the events of failure experienced by each specimen during the load, namely elastic part (crack incident no 1), nonlinear part (crack incident no 2) and ultimate loading (crack incident no 3). The crack pattern gained in the FE analysis for Beam A1, A2, $\mathrm{B} 1$ and $\mathrm{C} 2$ indicated that the specimens experienced flexure and shear failure. Diagonal cracks (crack incident no 3) propagated during later stages of loading and failure existed in the compression zone near the support and loading point.

On the other hand, Beam C3 experienced less brittle behaviour and the flexural cracks were present in several locations. Diagonal cracks appeared (crack incident no 3) during the final stage of loading in the compression zone and caused the crushing of the concrete under the loading plate and above the support plate.

\subsection{Load-Displacement Response}

Figure 6 compares the load-displacement relationship for all beams obtained from the experiment and 2D analysis with the load-displacement obtained from the 3D FE analysis in this study. The $2 \mathrm{D}$ analysis was conducted by Vecchio and Shim [11] by using the DSTM model. DSTM employed a smeared rotating crack approach by considering the compression softening effect in the concrete and divergence of principal stress and principal strain directions.

Load-deflection responses show that the peak load in the $2 \mathrm{D}$ analysis were overestimated but the displacements at failure were overly underestimated. Reliable modelling using $2 \mathrm{D}$ analysis was challenging since the tensile strength of concrete and out-of-plane confinement effects had a significant role in the nonlinear behaviour of RC beams. Load-displacement responses for all specimens gained with the $2 \mathrm{D}$ analysis showed that the model failed to reach the respective ultimate displacement. The strength and ductility in the concrete were not considered in the $2 \mathrm{D}$ analysis model so unexpected concrete crushing occurred under support and loading plate [11].

Load-displacement responses gained in $3 \mathrm{D} \mathrm{FE}$ analysis using Abaqus matched the load-displacement response in the experiment. In this study, the proposed approach captured the experimental behaviour in terms of peak load and displacement at failure. In terms of stiffness before cracking, load-deflection responses for the $3 \mathrm{D}$ analysis were in close agreement with the observed responses in the experiment. The modulus of elasticity as suggested in Equation 3 gave more accurate predictions. Furthermore, the $3 \mathrm{D}$ analysis revealed a flat ultimate load plateau in the latter phases of loading, demonstrating the same ductility response to the experiments. 


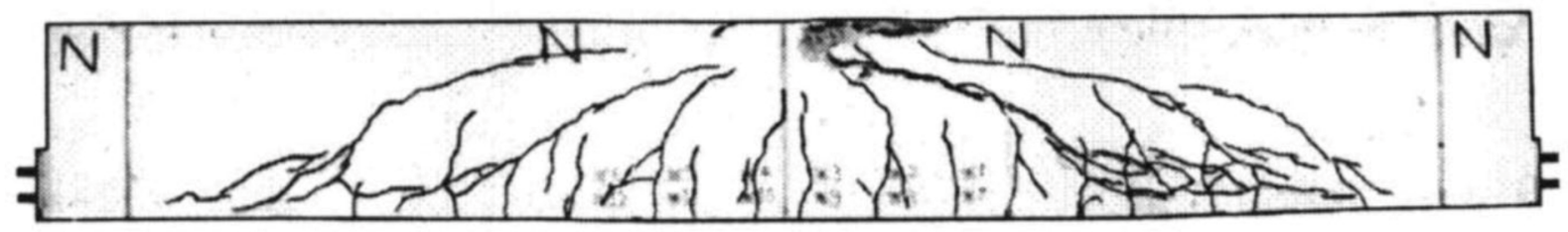

VS-A1

(a) Beam A1 - Experiment
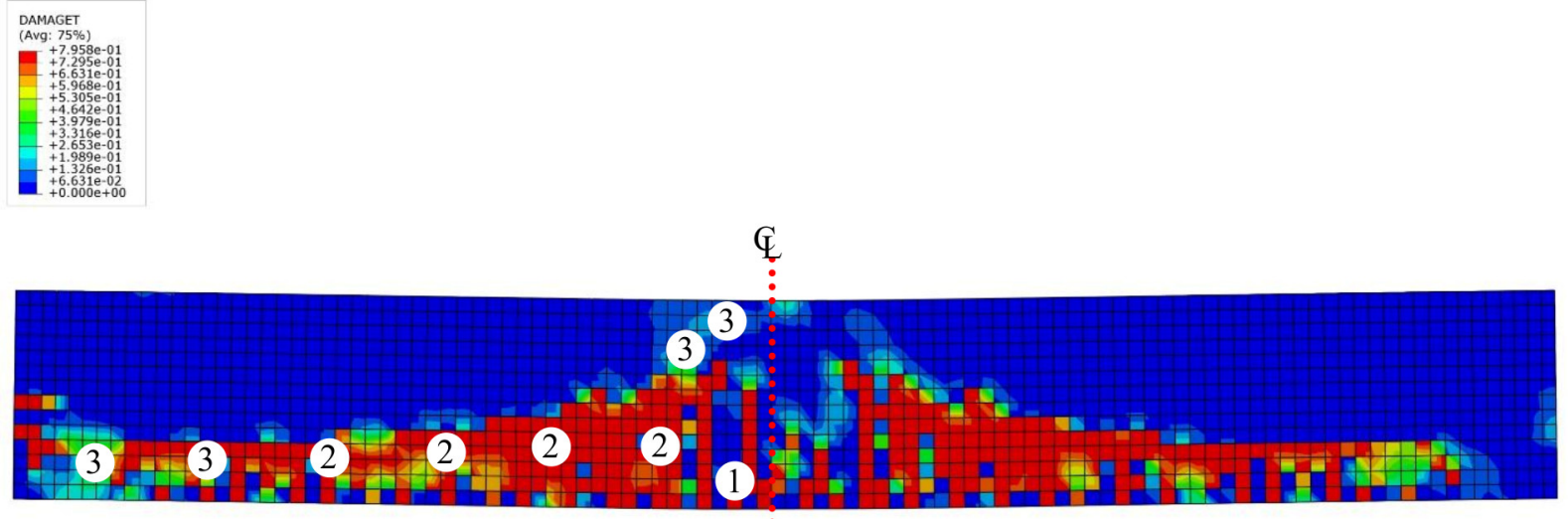

(b) Beam A1 - FE analysis

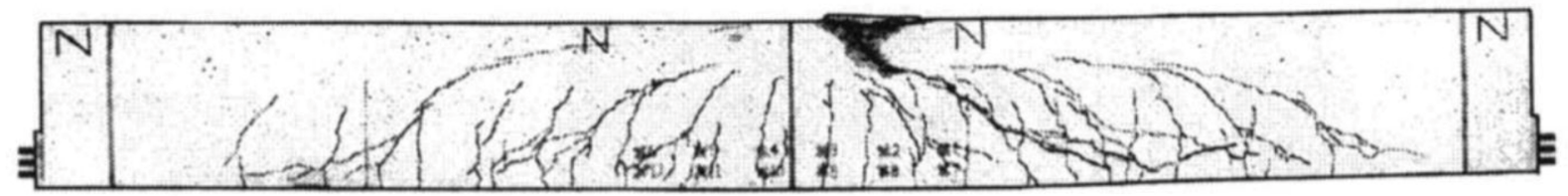

VS-A2

(c) Beam A2 - Experiment
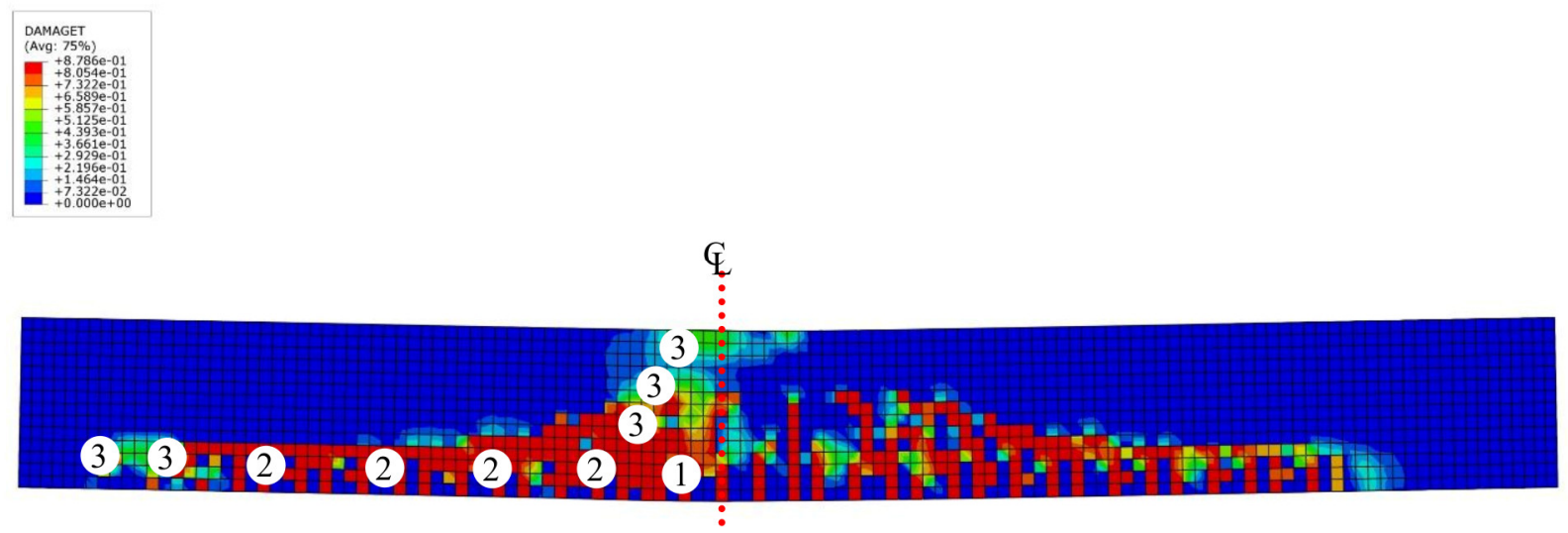

(d) Beam A2 - FE analysis

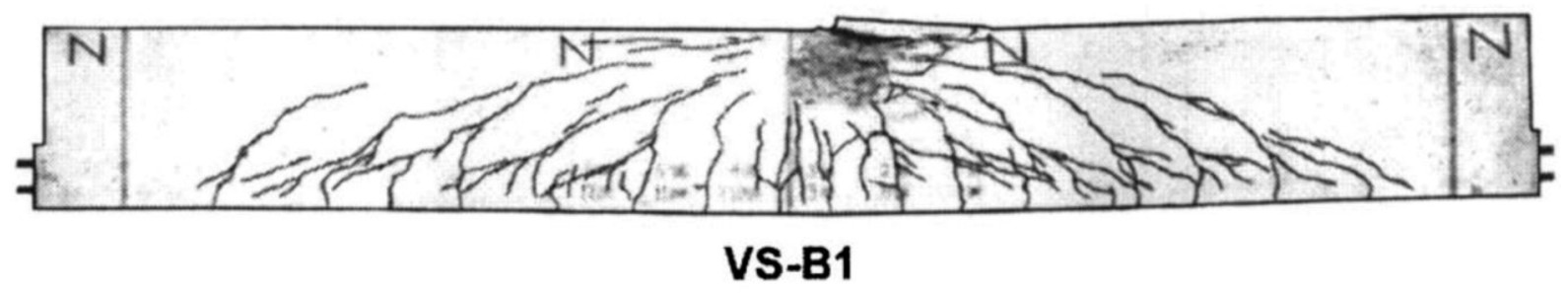

(e) Beam B1 - Experiment 

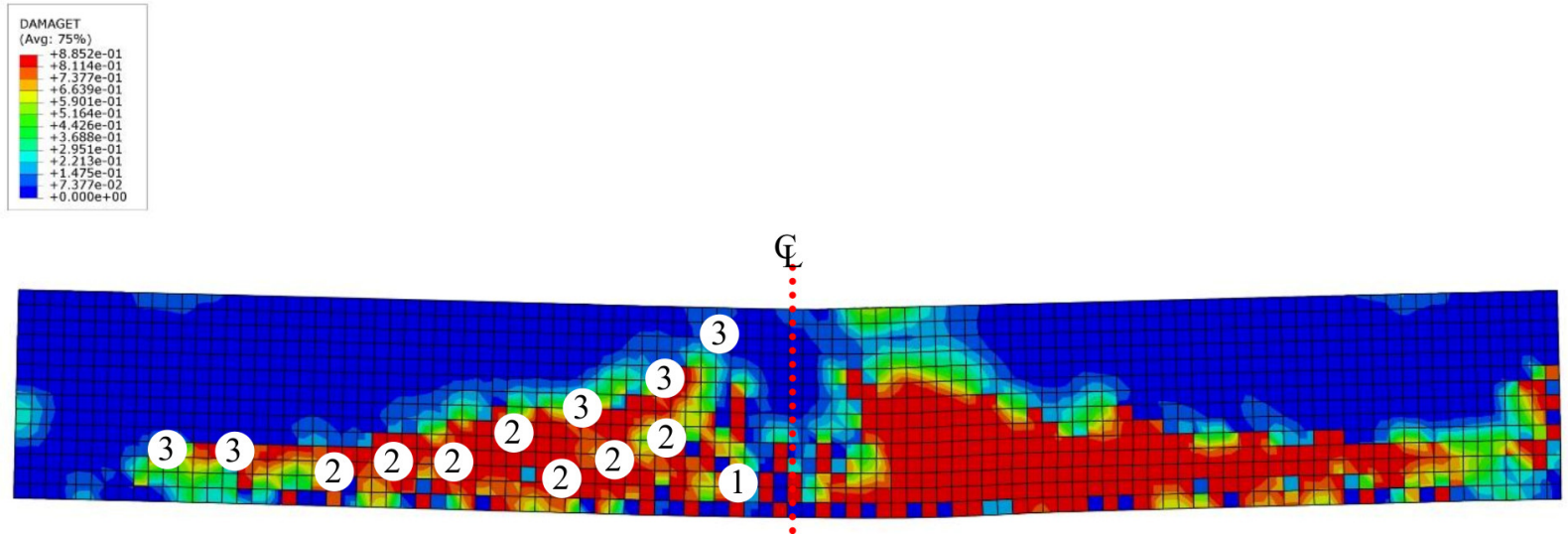

(f) Beam B1 - FE analysis

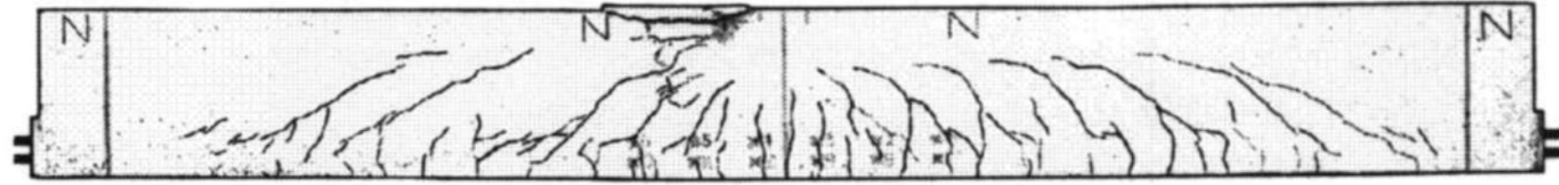

\section{VS-C2}

(g) Beam C2 - Experiment
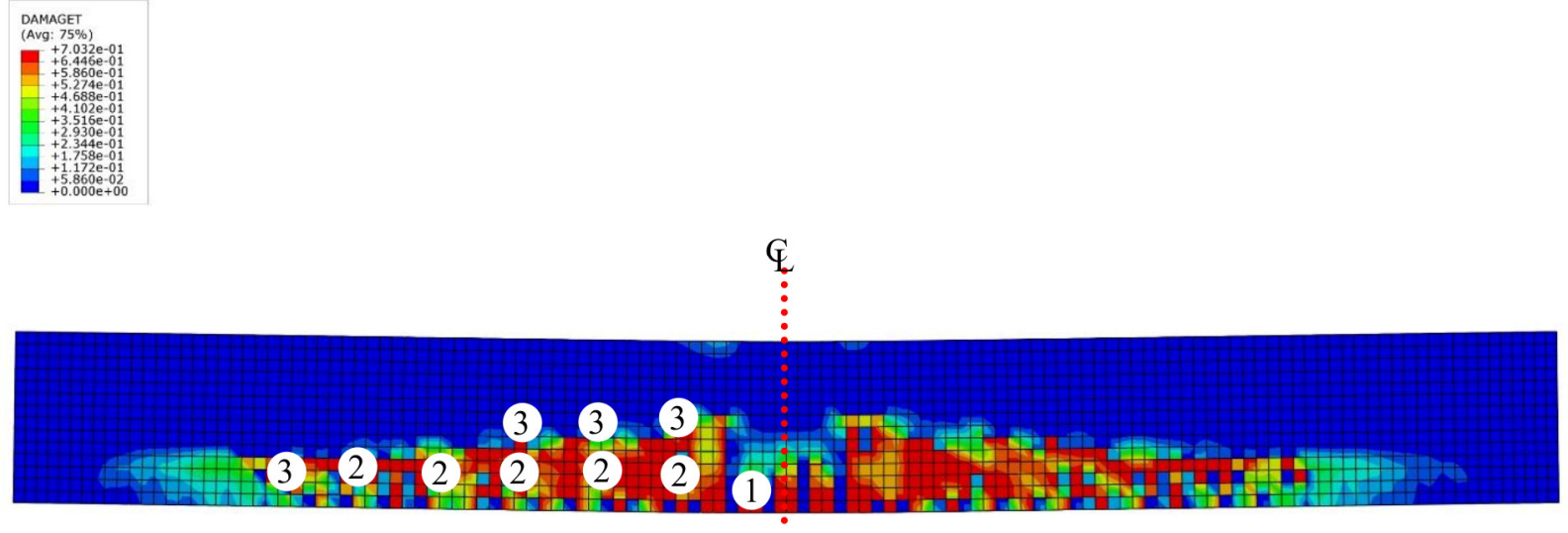

(h) Beam C2 - FE analysis

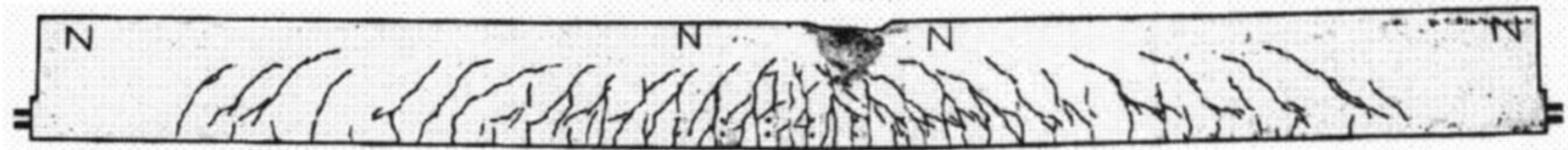

VS-C3

(i) Beam C3 - Experiment

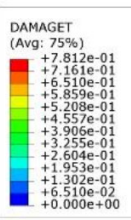

$$
\begin{gathered}
\mathrm{E} \\
\vdots \\
\vdots
\end{gathered}
$$

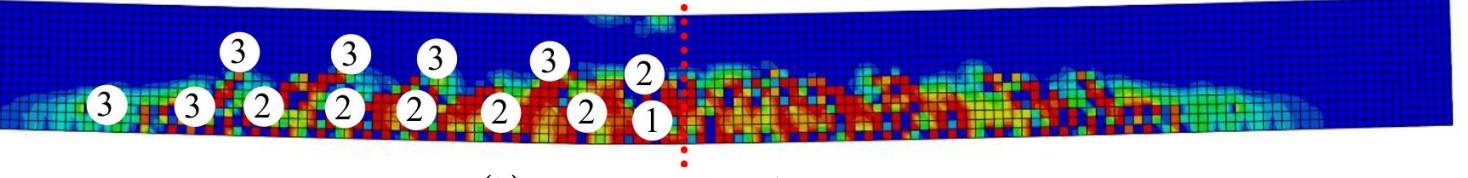

(h) Beam C3 - FE analysis

Fig. 5. Comparison of crack patterns between the experiment [11] and the FE analysis 

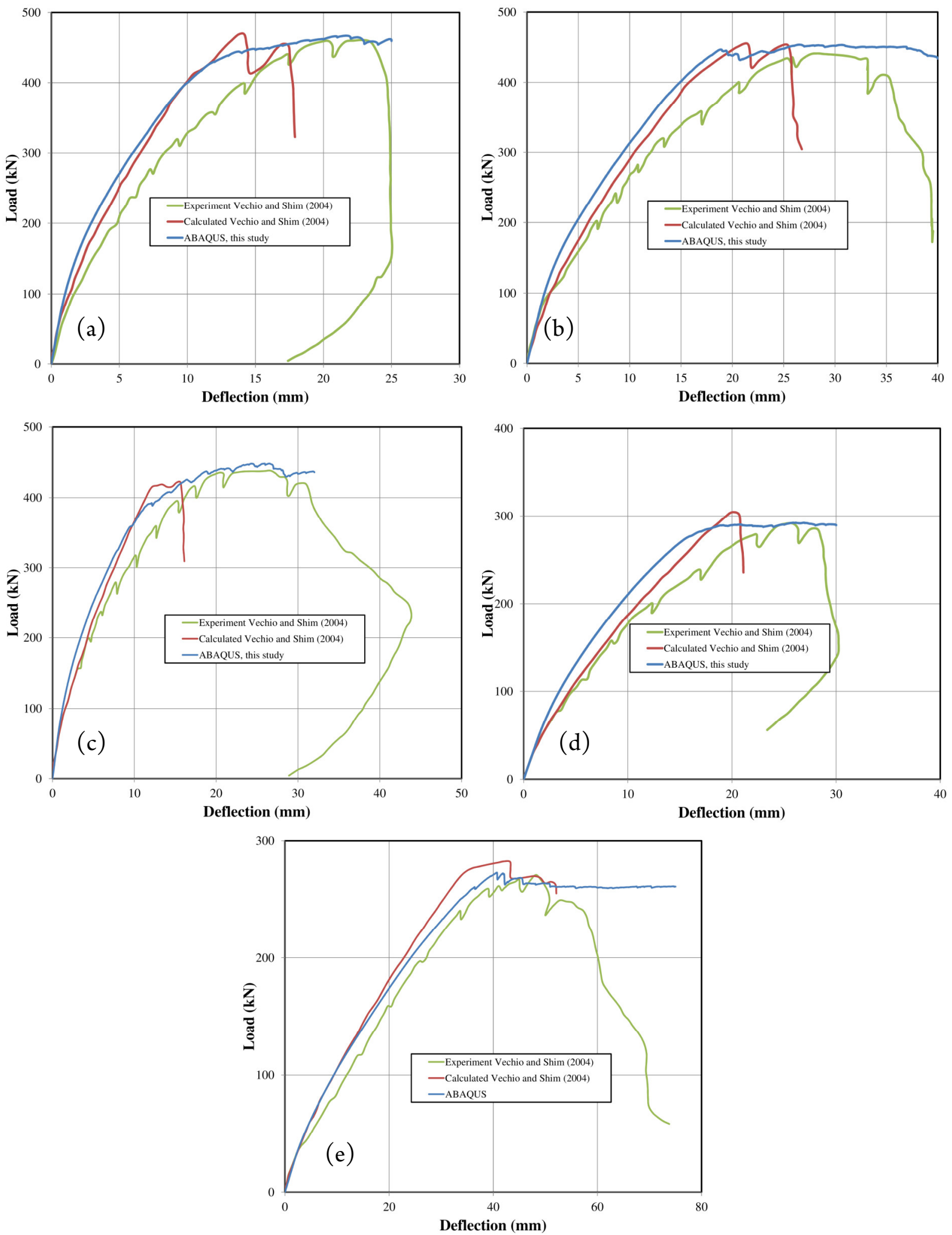

Fig. 6. Comparison of load-displacement response of Experiment and 2D analysis [11] VS 3D FE analysis

Table 4 shows the difference of the ultimate load and the displacement at ultimate load between $2 \mathrm{D}$ analysis and $3 \mathrm{D}$ analysis to the experiment results. Estimates of strength and the load-deformation response of $3 \mathrm{D}$ analysis were certainly achieved with reasonable accuracy compared to that of $2 \mathrm{D}$ analysis. The difference of experiment-to-2D strength $\left(P_{u, \exp }-P_{u, 2 D} / P_{u, \text { exp }}\right)$ had a mean of 4.53 whereas the difference of experiment-to-3D strength $\left(P_{u, \exp }-P_{u, 3 D} / P_{u, \exp }\right)$ had a mean of 1.83 . The displacements at ultimate load gained in the 3D analysis were comparable to those of experiments. Furthermore, compared to the $2 \mathrm{D}$ analysis, the 3D FE model proposed in this study performed better. The difference of experiment-to-2D $\left(\delta_{u, e x p}-\delta_{u, 2 D} / \delta_{u, \exp }\right)$ and experiment-to-3D $\left(\delta_{u, \text { exp }}-\delta_{u, 3 D} / \delta_{u, \text { exp }}\right)$ midspan displacement had a mean of 19.91 and 10.89 , respectively. 
Table 4 Comparison of Experiment and 2D analysis [11] VS 3D FE analysis at failure

\begin{tabular}{cccccccccccc}
\hline $\begin{array}{c}\text { Beam } \\
\text { IDs }\end{array}$ & \multicolumn{2}{c}{ Experiment [11] } & \multicolumn{2}{c}{ Calculated [11] } & Abaqus (this study) & \multicolumn{2}{c}{$\begin{array}{c}\text { Difference } \\
\text { Experiment to } \\
\text { Calculated }\end{array}$} & \multicolumn{2}{c}{$\begin{array}{c}\text { Difference } \\
\text { Experiment to } \\
\text { Abaqus }\end{array}$} \\
\hline (a) & $(\mathrm{b})$ & $(\mathrm{c})$ & $(\mathrm{d})$ & $(\mathrm{e})$ & $(\mathrm{f})$ & $(\mathrm{g})$ & $(\mathrm{h})$ & $(\mathrm{i})$ & $(\mathrm{j})$ & $(\mathrm{k})$ \\
& $\mathrm{P}_{\mathrm{u}}(\mathrm{kN})$ & $\mathrm{d}_{\mathrm{u}}(\mathrm{mm})$ & $\mathrm{P}_{\mathrm{u}}(\mathrm{kN})$ & $\mathrm{d}_{\mathrm{u}}(\mathrm{mm})$ & $\mathrm{P}_{\mathrm{u}}(\mathrm{kN})$ & $\mathrm{d}_{\mathrm{u}}(\mathrm{mm})$ & $\mathrm{P}_{\mathrm{u}}(\%)$ & $\mathrm{d}_{\mathrm{u}}(\%)$ & $\mathrm{P}_{\mathrm{u}}(\%)$ & $\mathrm{d}_{\mathrm{u}}(\%)$ \\
$\mathrm{A} 1$ & 459.0 & 18.8 & 476.0 & 14.3 & 457.6 & 23.2 & 3.70 & 23.94 & 0.30 & 23.56 \\
$\mathrm{~A} 2$ & 439.0 & 29.1 & 457.0 & 21.8 & 452.3 & 29.8 & 4.10 & 25.09 & 3.02 & 2.55 \\
$\mathrm{~B} 1$ & 434.0 & 22.0 & 423.0 & 15.8 & 446.3 & 26.9 & 2.53 & 28.18 & 2.84 & 22.24 \\
$\mathrm{C} 2$ & 290.0 & 25.7 & 306.0 & 20.6 & 291.9 & 26.0 & 5.52 & 19.84 & 0.64 & 1.17 \\
$\mathrm{C} 3$ & 265.0 & 44.3 & 283.0 & 43.2 & 271.2 & 42.1 & 6.79 & 2.48 & 2.33 & 4.94 \\
\hline
\end{tabular}

\section{CONCLUSION}

3D finite element analysis to determine the behaviour of shear-dominant responses of RC beams had been conducted in this study. Based on the results, the conclusions were drawn:

1. Crack propagation in the FE analysis matched the cracks observed in the test. The crack pattern on Beam $\mathrm{A} 1, \mathrm{~A} 2, \mathrm{~B} 1$ and $\mathrm{C} 2$ indicated that the specimens experienced flexure and shear failure while Beam C3 experienced less brittle behaviour.

2. Estimates of strength and the load-deformation response of $3 \mathrm{D}$ analysis were certainly achieved with reasonable accuracy compared to that of $2 \mathrm{D}$ analysis. The difference of experiment-to-2D strength $\left(P_{u, \exp }-P_{u, 2 D} / P_{u, \text { exp }}\right)$ had a mean of 4.53 whereas the difference of experiment-to-3D strength $\left(P_{u, \exp }-P_{u, 3 D} /\right.$ $\left.P_{u, \text { exp }}\right)$ had a mean of 1.83 .

3. Furthermore, the displacements at ultimate load gained in the $3 \mathrm{D}$ analysis were comparable to those of experiments. The difference of experiment-to-2D $\left(\delta_{u, \exp }-\delta_{u, 2 D} / \delta_{u, \exp }\right)$ and experiment-to-3D $\left(\delta_{u, \exp }\right.$ $\left.\delta_{u, 3 D} / \delta_{u, \text { exp }}\right)$ midspan displacement had a mean of 19.91 and 10.89 , respectively.

\section{AUTHOR INFORMATION}

\section{Corresponding Author}

*Email: ridwan@eng.unri.ac.id

\section{ORCID}

Ridwan

: 0000-0002-4582-0251

\section{REFERENCES}

[1] Park R, Paulay T. Reinforced Concrete Structures. New York: John Wiley \& Sons, Inc.; 1975.

[2] Kwak H-G, Kim S-P. Nonlinear analysis of RC beams based on moment-curvature relation. Comput Struct. 2002;80(7):615-28, DOI:10.1016/S0045-7949(02) 00030-5

[3] Stramandinoli RSB, La Rovere HL. FE model for nonlinear analysis of reinforced concrete beams considering shear deformation. Eng Struct. 2012;35:244-53, DOI:10.1016j.engstruct.2011.11.019

[4] Holzer Siegfried M, Somers Arnold E, Bradshaw Joel C. Finite Response of Inelastic RC Structures. Journal of the Structural Division. 1979;105(1):17-33, DOI:10.1061/JSDEAG.0005076

[5] Spacone E, Filippou FC, Taucer FF. Fibre BeamColumn Model for Non-Linear Analysis of R/C Frames: Part I. Formulation. Earthquake Engng Struct Dyn. 1996;25(7):711-25, DOI:10.1002/(SICI)10969845(199607)25:7<711::AID-EQE576>3.0.CO;2-9

[6] Ceresa P, Petrini L, Pinho R. Flexure-Shear Fiber Beam-Column Elements for Modeling Frame Structures Under Seismic Loading - State of the Art. J Earthquake Eng. 2007 ; 11(sup1): 46-88, DOI: $10.1080 / 13632460701280237$

[7] Frank JV, Michael PC. Predicting the Response of Reinforced Concrete Beams Subjected to Shear Using the Modified Compression Field Theory. ACI Struct J. 1988;85(3), DOI:10.14359/2515

[8] Vecchio FJ. Towards Cyclic Load Modeling of Reinforced Concrete. ACI Struct J. 1999;96(2), DOI: $10.14359 / 610$

[9] Palermo D, Vecchio FJ. Compression field modeling of reinforced concrete subjected to reversed loading: Formulation. ACI Struct J. 2003;100(5):616-25

[10] Bentz EC. Sectional Analysis of Reinforced Concrete Members: University of Toronto; 2000.

[11] Vecchio FJ, Shim W. Experimental and Analytical Reexamination of Classic Concrete Beam Tests. J Struct Eng. 2004;130(3):460-9, DOI:10.1061/ (ASCE)0733-9445(2004)130:3(460)

[12] Abaqus. ABAQUS analysis : user's manual. Providence, Rhode Island: ABAQUS Inc.; 2008.

[13] Danesh F, Esmaeeli E, Alam MF. Shear Strengthening of 3D RC Beam-Column Connection Using GFRP: FEM Study. Asian Journal of Applied Sciences. 2008;1:217-27, DOI:10.3923/ajaps.2008.217.227

[14] Abbas AA, Mohsin SMS, Cotsovos DM. Seismic response of steel fibre reinforced concrete beam-column joints. Eng Struct. 2014;59:261-83, 
DOI:10.1016/j.engstruct.2013.10.046

[15] Gebreyohaness AS. Seismic Assessment of Pre-1936 Dual RC Wall-Riveted Steel Frame Buildings: University of Auckland; 2013.

[16] Othman H, Marzouk H. Finite-Element Analysis of Reinforced Concrete Plates Subjected to Repeated Impact Loads. J Struct Eng. 2017;143(9):04017120, DOI:10.1061/(ASCE)ST.1943-541X.0001852

[17] Chandra N, Ridwan R, Ikhsan M. Finite element modelling of reinforced concrete beam strengthened with embedded steel reinforcement bars. J Appl Mat and Tech. 2019;1(1):38-45, DOI:10.31258/ jamt.1.1.38-45

[18] Lubliner J, Oliver J, Oller S, Onate E. A PlasticDamage Model for Concrete. Int J Solids Struct. 1989;25(3):299-326, DOI:10.1016/0020-7683(89) 90050-4

[19] Lee JH, Fenves GL. Plastic-Damage Model for Cyclic Loading of Concrete Structures. J Eng Mech-Asce. 1998;124(8):892-900, DOI:10.1061/(Asce)07339399(1998)124:8(892)
[20] CEB-FIP. Comité Euro-International du BétonFédération Internationale de la Précontrainte (CEB-FIP) model code 1990. Lausanne, Switzerland: Comite Euro-International du Beton; 1993. 437 p, DOI:10.1680/ceb-fipmc1990.35430

[21] Bazant ZP, Planas J. Fracture and Size Effect in Concrete and Other Quasibrittle Materials. 1st Edition ed. Boca Raton: Taylor and Francis; 1998. DOI:10.1201/9780203756799

\section{This article is licensed under a Creative Commons} Attriution 4.0 International License 